\title{
The Ulster Cycle: Cultural Significance for Irish Composers
}

\author{
Angela Goff \\ Waterford Institute of Technology
}

Copyright (c) 2017 by Angela Goff. This text may be archived and redistributed both in electronic form and in hard copy, provided that the author and journal are properly cited and no fee is charged for access.

\begin{abstract}
For more than three hundred years, Irish composers have engaged with tales from early Irish saga-literature which comprises four main series: Mythological, Ulster and Fenian cycles as well as the Cycle of Kings. This literary corpus dates from 600-1200 CE and is amongst the oldest in Europe. The fragmented history of the literature reveals a continuity of tradition in that the ancient sagas evolved from the oral Irish tradition, were gradually recorded in Irish, and kept alive in modern times through translation into the English language. The timelessness and social impact of these sagas, centuries after they were documented, resonate with Irish composers through the identification of local features and/or universal themes of redemption, triumph or tragedy depicted in the literature. The focus here is on sagas from the Ulster Cycle as they have been most celebrated by Irish composers; the majority of which have been composed since Thomas Kinsella's successful translation of the Táin Bó Cuailnge in 1969. How the composers chose to embrace the Irish past lies in each composer's execution of the peculiar local and universal themes exhibited in the sagas. The aim of this article is to initiate an interdisciplinary discussion of the cultural significance of this literary corpus for Irish composers by exploring an area of Irish musicological discourse that has not been hitherto documented. A brief literary background to the Ulster Cycle leads to a discussion of what prompted the composers to engage with Ulster Cycle themes at a particular time in their respective careers. An exploration of the various stylistic features employed in selected works sheds light on the cultural ideologies that prevailed in Ireland at the time of their respective composition.
\end{abstract}

Key Words. Musicology, Irish Literature, Irish History, Celtic Studies, Cultural Studies.

Resumen. Desde hace más de trescientos años los compositores irlandeses han buscado inspiración en los cuentos de las antiguas sagas irlandesas, las cuales se dividen principalmente en cuatro grupos: mitológicas, del Ulster, Fenianas y el Ciclo de los Reyes. Este corpus, entre los más antiguos de Europa, se remonta a los años 600-1200 de nuestra era. La historia fragmentada de la literatura revela no obstante una continuidad en la tradición, en el sentido de que las antiguas sagas evolucionaron desde la tradición oral, se recogieron en documentos escritos en irlandés y se mantuvieron vivas en la época actual por medio de la 
traducción al inglés. El impacto de estas sagas, así como su atemporalidad, siglos después de haber sido domumentadas, se demuestra por el eco que encontraron en los compositores irlandeses a través de la identificación de características locales y de temas universales, tales como la redención, el triunfo y la tragedia, tal y como se mostraban en la literatura. Este artículo se centra en las sagas del Ciclo del Ulster, las que más han sido tratadas por los compositores irlandeses. La mayoría se compusieron a raíz de la famosa traducción de Táin Bó Cualilnge en 1969 por parte de Thomas Kinsella. La ejecución por parte de los distintos compositores de los temas locales y las preocupaciones universales que contienen las sagas, muestra el enfoque con el que cada uno de ellos se acercó al pasado irlandés. Este artículo prentende iniciar una discusión interdisciplinar sobre el significado cultural de este corpus literario para los compositores irlandeses, explorando un área de la musicología irlandesa que hasta ahora no ha sido lo suficientemente investigada. Tras una breve exposición de los textos que contienen el Ciclo del Ulster, se examinrán las razones que llevaron a los distintos compositores a interesarse por este ciclo en determinados momentos de sus carreras. Un estudio de las características de las obras seleccionadas puede desvelar la ideología predominante en Irlanda en el momento de su composición.

Palabras clave. Musicología, literatura irlandesa, historia de Irlanda, estudios celtas, estudios culturales.

\section{Introduction}

For more than three hundred years, Irish composers have engaged with tales from early Irish saga-literature which comprises four main series: Mythological, Ulster and Fenian cycles as well as the Cycle of Kings. This literary corpus dates from 600-1200 CE and is amongst the oldest in Europe. The fragmented history of the literature reveals a continuity of tradition in that the ancient sagas evolved from the oral Irish tradition, were gradually recorded in Irish, and kept alive in modern times through translation into the English language. The timelessness and social impact of these sagas, centuries after they were documented, resonate with Irish composers through the identification of local features and/or universal themes of redemption, triumph or tragedy depicted in the literature. Sagas from the Ulster Cycle have been most celebrated by Irish composers; the majority of which have been composed since Thomas Kinsella's successful translation of the Táin Bó Cuailnge in 1969. Although the Táin is the centrepiece of the Cycle, the compositions that reference the Ulster Cycle highlight the characters of Déirdre and Cú Chulainn as being most inspiring to musical interpretation; all of which are Listed in Table $1 .{ }^{1}$ How the composers chose to embrace the Irish past lies in each composer's execution of the peculiar local and universal themes exhibited in the sagas. The aim of this study is to initiate an interdisciplinary discussion of the cultural significance of this literary corpus for Irish composers by exploring an area of Irish musicological discourse that has not been hitherto documented. ${ }^{2}$ A brief literary background to the Ulster Cycle leads to a discussion of the works listed in Table 1: what prompted the composers to engage with the past by employing Ulster Cycle themes at a particular time in their respective careers precedes an exploration of the various stylistic features employed in a selection of the works in order to shed light on the cultural ideologies that prevailed in Ireland at the time of their respective composition. 
Table 1: Ulster Cycle-themed works by Irish Composers

\begin{tabular}{|c|c|c|}
\hline Year & Chronology of Compositions & Composer \\
\hline 1897 & $\begin{array}{l}\text { Déirdre } \\
\text { Text: T. W. Rolleston }\end{array}$ & $\begin{array}{l}\text { Esposito, Michele } \\
1855-1929\end{array}$ \\
\hline $\begin{array}{l}\text { c.192 } \\
\text { 0 }\end{array}$ & $\begin{array}{l}\text { The Garden of Fand (precise date } \\
\text { unknown) }\end{array}$ & $\begin{array}{l}\text { Stanford, Charles V. } \\
1852-1924\end{array}$ \\
\hline 1925 & $\begin{array}{l}\text { Deirdre of the Sorrows } \\
\text { Text: W. M. Crofton }\end{array}$ & $\begin{array}{l}\text { Palmer, Geoffrey } \\
1882-1957\end{array}$ \\
\hline 1938 & Deirdre & $\begin{array}{l}\text { Ó Gallchobháir, } \\
\text { Éamonn } \\
1900-1982\end{array}$ \\
\hline 1955 & $\begin{array}{l}\text { Macha Ruadh } \\
\text { Scenario: Adaptation by Myles Dillon }\end{array}$ & $\begin{array}{l}\text { Fleischmann, Aloys } \\
\text { 1910-1992 }\end{array}$ \\
\hline 1971 & $\begin{array}{l}\text { The Táin } \\
\text { Text: Adapted by Ian Fox / Kinsella's } \\
\text { The Tain }\end{array}$ & $\begin{array}{l}\text { Wilson, James } \\
\text { 1922-2005 }\end{array}$ \\
\hline 1974 & $\begin{array}{l}\text { Fand (1974) } \\
\text { Text: Adapted by Wilson from J. } \\
\text { MacDonald translation }\end{array}$ & $\begin{array}{l}\text { Wilson, James } \\
\text { 1922-2005 }\end{array}$ \\
\hline 1979 & $\begin{array}{l}\text { I have Loved the Lands of Ireland } \\
\text { (Symphony No. 2) }\end{array}$ & $\begin{array}{l}\text { Bodley, Seóirse } \\
\text { b. } 1933\end{array}$ \\
\hline 1981 & $\begin{array}{l}\text { The Táin } \\
\text { Scenario: Adapted by Fleischmann \& J. } \\
\text { D. Moriarty / Kinsella's The Tain }\end{array}$ & $\begin{array}{l}\text { Fleischmann, Aloys } \\
\text { 1910-1992 }\end{array}$ \\
\hline 1983 & $\begin{array}{l}\text { The Only Jealousy of Emer } \\
\text { Text: W. B. Yeats }\end{array}$ & $\begin{array}{l}\text { Wilson, James } \\
\text { 1922-2005 }\end{array}$ \\
\hline 1989 & $\begin{array}{l}\text { Déirdre } \\
\text { Text: Ulick O'Connor }\end{array}$ & $\begin{array}{l}\text { Sweeney, Eric } \\
\text { b. } 1948\end{array}$ \\
\hline 1994 & $\begin{array}{l}\text { Caoineadh Cu Chulainn } \\
\text { (Lament) }\end{array}$ & $\begin{array}{l}\text { Whelan, Bill } \\
\text { b. } 1950\end{array}$ \\
\hline 1994 & Of the Táin & $\begin{array}{l}\text { Gribbin, Déirdre } \\
\text { b. } 1967\end{array}$ \\
\hline 1997 & Macha's Curse & $\begin{array}{l}\text { Alcorn, Michael } \\
\text { b. } 1962\end{array}$ \\
\hline 1998 & Deirdre of the Sorrows CD & $\begin{array}{l}\text { Cassidy, Patrick } \\
\text { b. } 1956\end{array}$ \\
\hline 2000 & $\begin{array}{l}\text { Sétanta } \\
\text { Text: Adapted by Farrell / Kinsella's } \\
\text { The Tain }\end{array}$ & $\begin{array}{l}\text { Farrell, Eibhlís } \\
\text { b. } 1953\end{array}$ \\
\hline 2000 & Morríghan & $\begin{array}{l}\text { Johnston, Fergus } \\
\text { b. } 1959\end{array}$ \\
\hline 2008 & $\begin{array}{l}\text { Cuchulainn \& Ferdia - Duel at the } \\
\text { Fiord }\end{array}$ & $\begin{array}{l}\text { Kinsella, John } \\
\text { b. } 1932\end{array}$ \\
\hline
\end{tabular}

\section{Literary Contextualisation of the Compositions}

This brief literary background to the Ulster Cycle serves to contextualise the origins of the subject-matter which has inspired Irish composers. The Ulster Cycle comprises a large body 
of tales which exhibit rich lives of bravery and love that relate to the heroic adventures of the Ulaid - a pre-historic people who lived in the north-east of Ireland and from whom the modern name Ulster originates. Tales from the Ulster Cycle are thought to be set in the first century before the birth of Christ and pre-Christian divinities, such as sun worship and the veneration of natural objects prevail in the stories. The heroic exploits of Cú Chulainn feature in several of the interrelated tales that make up the Táin Bó Cuailnge (Cattle-Raid of Cooley), which is the centrepiece of the Ulster Cycle. The epic content of the Táin for example tells of how Queen Medb of Connacht's jealous greed to surpass her husband's wealth results in her waging war against the people of Ulster in order to steal the valuable Brown Bull of Cooley. The defence of the province is left to the seventeen-year-old Cú Chulainn who kills all who dare to challenge him, including his foster brother, Fer Diad. Medb eventually succumbs to defeat. The epic content of the Táin can be considered to be a tragic, or romantic, narrative. The catastrophic results that emerge from Medb's greed reveal a tragic mythos whereas Cú Chulainn's god-like status typically features a romantic idealisation of the mythical hero.

The dissemination of the sagas from the Ulster Cycle has evolved from the vibrant oral tradition from which they were recorded from the eighth to the eleventh centuries and written sources are found in vellum manuscripts dating from the end of the eleventh century. These include: the earliest extant Book of the Dun Cow (Lebor na hUidre, LU), believed to have been written before 1106 (Dillon xvii) and is preserved in the Royal Irish Academy, Dublin; the twelfth-century Book of Leinster (Lebor Núachongbála, LL) and the fourteenth- or early fifteenth-century Yellow Book of Lecan (YBL), both of which are housed in the library of Trinity College, Dublin.

These ancient manuscripts are still being mined for information and, as the Irish historian Muireann Ní Bhrolcháin states, "the study of early Irish sagas and related texts as literature is really in its infancy and dates from the late 1940s". She explains that previous research focused "on the linguistic aspect of the texts with very little attention to the content" and that a more "holistic view of the literature and its relationship with history and archaeology in particular" is slowly evolving (151-2). In reference to the Ulster Cycle, linguistic research provides evidence that much of the embedded literature in the surviving manuscripts pre-dates the composition of the texts. From the time of their initial transcription into the ancient manuscripts, the sagas have been translated and interpolated, resulting in several versions of each. For instance, there are many arguments as to the origins of the Táin; the eminent scholar of Celtic languages, Cecile O'Rahilly, claims that it exists in three recensions ("Introduction" vii) whereas, almost thirty years later, the poet and translator Ciaran Carson asserts that it has been composed from two main recensions (xiii). Since the Book of Leinster contains the most complete version of the saga, it has naturally become the most consulted manuscript on the subject.

Approbation for tales from the Ulster Cycle in the English language occurred during the late nineteenth century when cultural nationalists explored the ancient manuscripts in search of heroic Irish figures to replace those imposed on local children by English-run schools. The heroic deeds of the Ulster King, Conor (Conchobhar) mac Nessa, and particularly the Red Branch warriors began to feature in the poetry of Thomas Moore (1779-1852), such as the poem "Let Erin Remember" which was published in 1808. At the turn of the twentieth century, other prominent characters from the Cycle such as Conchobhar's most famous warrior, Cú Chulainn, and the tragic heroine Déirdre, emerged in works by John Millington Synge (1871-1909), Lady Gregory (1852-1932) and William Butler Yeats (1865-1939); several of which have been employed by Irish composers. Despite German and French excerpts of the saga being published in 1905 and 1907 respectively, and L. Winifred Faraday's, The Cattle-Raid of Cooley (1904) being the first partial English translation from the earliest source of the Táin, it was not until the latter half of the twentieth century that 
translations from the various recensions were documented by O'Rahilly (1961, 1967 and 1976). However, the first complete and readable version of the saga, from its earliest form, was translated into the English language by Thomas Kinsella (1969). ${ }^{3}$ Almost forty years later, Ciaran Carson translated the Táin and admits that the 2007 publication "would not have been possible without Kinsella's ground-breaking text" (xxiv), thus highlighting the importance of Kinsella's work. While numerous characters feature in this literary corpus, the focus of Irish composers has been on: Cú Chulainn (also known by his boyhood name, Sétanta); the tragic heroine, Déirdre; the war goddesses Morrígan and Macha; Fand, wife of the sea god Manannán mac Lir; and the story of the Táin. What prompted the composers to engage with these characters and the depth of association applied to the literature determines how cultural influences affected the compositions.

\section{Cultural Significance of Ulster Cycle themes for Irish composers}

The earliest known work based on a saga from this literary corpus was composed during the Celtic Revival by an Italian immigrant who had recently settled in Ireland and immersed himself in the Dublin music scene. Michele Esposito's cantata entitled Déirdre (1897), based on an English language text by T. W. Rolleston, depicts the story of the tragic heroine who takes her own life as her true love Naoise, the son of Usnach, has been killed by King Conchobhar of Ulster who had been promised her hand in marriage. The work won a prize at the inaugural Feis Ceoil, which was a competition founded in 1897 to promote music in Irish cultural life. ${ }^{4}$ Having settled in Ireland (1882-1928), Esposito embraced the cultural revival of Irish music and folklore, hence the romantic tonal language of the opera is penetrated with Irish folk song and traditional dance influences. At the turn of the twentieth century Ireland was under British rule and this style of music was in keeping with the spirit of the revivalist movement which sought to protect Irish distinctiveness, as opposed to embracing any form of modernism such as the new concepts of tonality that were emerging in European composition. Since Irish traditional music was the music of the people, composers, particularly at the turn of the twentieth century, strove to create an Irish identity and incorporated airs from the ethnic idiom into their music.

It is worth noting that at the end of the nineteenth century, and well into the latter decades of the twentieth century, the Irish music scene comprised a lack of patronage, a poor music education system and impoverished infrastructures. In his paper "Nationalism and Irish Music", the Irish musician and musicologist, Joseph Ryan, highlights the various social, cultural and political issues that were a hindrance to the development of a strong art music tradition in Ireland. He believes that it is too easy to blame these circumstances, especially as impressive achievements had occurred in literature. Ryan also states that "the negligible creative output" of composers for the greater part of the past two centuries is largely due to the "puissant influence of nationalism on creative endeavour" (103). Despite the intolerable circumstances and the frequent insular attitudes of those who subscribed to a purely nationalist and Gaelic tradition, Ryan's claim that the output of Irish composers was "negligible" is easily refuted by a cursory glimpse at the listing of creative enterprise and musical activity discussed in the writings of Axel Klein and Aloys Fleischmann. ${ }^{5}$

The strength of Irish nationalism is further evidenced by the fact that the English composer, Arnold Bax (1883-1953), who had lived in Dublin in the years leading to World War I, became fascinated with the Cultural Revival and immersed himself in the Dublin literary scene, frequently writing under the pseudonym, Dermot O'Byrne. During his time in Ireland, he composed an orchestral overture entitled The Garden of Fand (1916, 1921), and an unfinished opera, or five-act drama, Déirdre (c. 1907) which was inspired by W.B. Yeats's three-act play of the same name. Despite Déirdre being unfinished, perhaps due to Bax 
believing he was not a gifted opera composer, the music is significant in that several of the themes were used as a basis for his other works; The Gathering of the Chiefs march for example features in the tone poem Into the Twilight (1908). The march was later orchestrated for Roscatha (Battle Hymn, 1910) which has become the third part of the orchestral Éire trilogy. 6

During the twentieth century, Irish composition gradually progressed from insular to more cosmopolitan practices which reflect the various responses to the cultural and political ideologies of the time. The tendency towards cultural insularity is evident in the composition of several operas at the turn of the twentieth century which were inspired by early Irish sagaliterature, such as Geoffrey Molyneux Palmer's opera entitled Deirdre of the Sorrows (1925), set to a text by William Mervyn Crofton. ${ }^{7}$ At the time, travelling opera companies such as the Carl Rosa and the O'Mara Company provided opportunities to stage these productions. Due to ill-health, Palmer never finished the opera and it has not been performed despite being completed by the Belgian composer Staf Gebruers (1902-1970) who, in 1924, had taken up the position of Carillonneur, Organist and Choirmaster of St Colman's Cathedral in Cobh, Co. Cork. Although little of Palmer's work has survived, Deirdre of the Sorrows appears to be one of four operas based on Celtic themes that were written by the composer during the early twentieth century. Patriotism was very strong in Ireland throughout the opening decades of Ireland's independence (1922-42) when the revival and preservation of Ireland's culture was at the forefront of Irish cultural life. At that time, the dominating ideology of Irish tradition strove to create a self-sufficient country, without recourse to English or European developments. This may explain why Palmer includes a libretto written in the Irish language, by Thomas O'Kelly, in another opera based on the Children of Lir saga. Palmer's opera, Srúth na Maoile (The Straits of Moyle, 1923), premiered at the Gaiety Theatre, Dublin, July 1923, and was re-staged the following year by the O'Mara Opera Company. The central melodic motif of the opera comprises the setting of a poem by Thomas Moore "Silent, O Moyle" to the air Arrah, My Dear Eveleen and reflects the essentialist protection of Irish distinctiveness which dominated everyday life at that time.

The renowned Irish musicologist, Harry White, suggests that this type of "“classical music' became emblematic of colonial mismanagement and self-indulgence, the corresponding reliance on the ethnic repertory as a symbol of dispossession and political aspiration ruinously displaced the cultivation of music other than as a marker of cultural separatism." (The Progress 75). In seeking a separate Irish identity, composers gradually began to question and explore more progressive ways to employ the ethnic repertory, or not, in their music. This is evident in several works inspired by the Ulster Cycle where composers either rely on the Irish context of the saga, or transcend the setting of the text, in order to give their music meaning.

Despite Éamonn Ó Gallchobháir (1900-1982) being inspired by the ancient manuscripts of Ireland, his processional for dancers entitled Deirdre (1938) is his only work to reference a theme from the Ulster Cycle. However, in 1950 he composed a ballet entitled The Children of Lir which was based on a scenario by Patricia O'Reilly. In keeping with the cultural ideology of the time, Ó Gallchobháir was a strong advocate of Irish music nationalism. This concept was embraced by several other Irish composers, including Redmond Friel (1907-79), Thomas C. Kelly (1917-85) and Daniel McNulty (1920-96), who repudiated European developments in music in favour of the integration of Irish traditional melodies into classical forms. ${ }^{8}$ During the same time frame however, evidence of international contemporary techniques is apparent in works by Frederick May (191-85), Brian Boydell (1917-2000) and Aloys Fleischmann (1910-92) who were "outspoken opponents of narrow-minded musical nationalism" (Klein, "Roots" 176-177). ${ }^{9}$ In 1936 Fleischmann documented in the Ireland To-Day magazine, that achieving "new expression", in Gaelic art music, may breathe "the spirit of the traditional 
music" and maintained that "continuity of fidelity of tradition is not best achieved by atavism, by a slavish use of the material of the past" (Fleischmann, "Ars Nova" 45). Ó Gallchobháir disputed Fleischmann's reference to "atavism" and responded by stating that:

The sensitive mind in Ireland To-Day [1936] is still influenced by the same things and in the same way as was the sensitive mind in Ireland long ago. ... If a new music arise to express Ireland it can have as its root only the fundamental sense of values that belongs to the Irish mind, and it is conceivable that its strength will lie in its atavism. $(58)^{10}$

From the above discussion, it is evident that the ideology of nationalism had come into disrepute. By the 1950s, Irish revisionist historians abjured any sense of nationalism and this was further exacerbated by the social and political friction which led to the escalation of the "Troubles" in Northern Ireland. The result of T. K. Whittaker's foreign investment policies brought unprecedented growth to the Irish economy, which gave some viable hope that the republic could economically sustain a united Ireland; the idea of a united Ireland however, was not entertained by the homogeneous Protestant community in Northern Ireland. Irish revisionists sought to erode cherished nationalist ideals and values as they considered them to be anachronistic and consequently favoured a more inclusive, and pluralistic, ideology. While Irish composers were seeking to establish an art music tradition in Ireland, and engendering lively debate through an exchange of words in the reputable journals of the time, ${ }^{11}$ composers frequently looked elsewhere for inspiration for their works. Despite this, several composers managed to imbue their creative output with Irish literature and more modern techniques; however it took another fifty years before the tragic heroine, Déirdre, emerged in one of their works.

The cantata, Deirdre (1989), by Eric Sweeney (b. 1948), displays a pluralistic ideology in that the composer took a well-known Irish saga and treated "it in a deliberately non-Western way" (Sweeney, "A Folio" 12). Since Sweeney's minimalist compositional language is derived from non-Western music, it may seem natural that he should begin to explore methods of combining elements from the East and West. He discovered that the play entitled "Deirdre" by the notable Irish writer, poet and playwright, Ulick O'Connor (b. 1928), paralleled this idea of "East meets West". ${ }^{12}$ The play is in the style of Japanese Noh-Theatre "to create a mood for the audience, a feeling for the half-realised, which is connected with the Buddhist belief of re-incarnation" (Sweeney, Programme). The composer adapted the text to accommodate a musical structure and his cantata Deirdre incorporates both Irish traditional and Japanese influences. The principal character of a Noh play, for instance, discards his mandatory mask in order to re-tell the story and Sweeney illustrates this technique by the use of spoken (in the manner of a seanchai ) as opposed to sung text. In addition he includes a complete quotation of the Japanese lullaby, Ko-mori-uta, in the third and final movement of the work in order to highlight the poignancy of Deirdre's fate: "Deirdre's spirit will not be released until the Earth comes round again" (Sweeney, Programme). He also indicates that, when possible, Ko-mori-uta should be played on a shakuhachi which is a Japanese flute made of bamboo with four finger holes and a thumb hole.

In Deirdre, Sweeney takes the idea of East meets West a step further by employing two traditional Irish tunes, which are treated in a minimalist style. In the first movement for example, Sweeney introduces small fragments of "Macananty's Reel" at a time in order to create a type of pitch-series that develops into a polyrhythmic and multi-layered texture. In the second movement the a cappella chorus evokes a sense of suspended time with the eighteenth-century melody "The Lament of Donnacha of Ballea" which has a "series of static, yet constantly changing patterns which feature multiple canons and additive rhythms" 
(Sweeney, Programme). Sweeney explains that "Non-Western approaches together with local music may seem an unlikely combination but can, I feel, offer positive directions to explore" ("A Folio" 7). Since asserting this belief in 1994, Sweeney's output has continued to integrate Irish folkloristic elements with minimalist techniques. Thus the Irish musicologist Hazel Farrell has described his compositional language as "Hiberno-minimalism" (258). The composer's reliance on Irish traditional folk tunes as a source of pitch material in several of his works, does not mean that he is trying to convey an Irish sound. Instead his personal language exhibits an internationally-influenced plurality. He draws inspiration from a variety of composers, including Bartók, Stravinsky and Britten, thus integrating folkloristic elements within a contemporary context. The composer's only other work stemming from early Irish literature is the cantata entitled Niamh of the Golden Hair which is based on the Tír na nÓg episode from the Fenian Cycle. ${ }^{13}$

Mayo-born Patrick Cassidy's Deirdre of the Sorrows (1998) is the most recent work to be inspired by the tragic heroine. Although the score of this work is unavailable for research purposes, its significance lies in the fact that it is one of the few works based on a tale from the Ulster Cycle that has been commercially recorded. In 1998, Deirdre of the Sorrows was recorded by the London Symphony Orchestra and BMG/ Windham Hill Records. Similar to other Irish composers almost a century before, Cassidy not only engages with a tragic theme from the Ulster Cycle but also embraces the redemptive saga, "The Children of Lir". Set in the Irish language, The Children of Lir (1991) has been commercially released by several labels with the original recording, by Son Records (Abbey Road, London, 1993), performed by the celebrated Tallis Choir and the London Symphony Orchestra. Cassidy, renowned for his film scores, currently resides in Los Angeles and one of his most recent works, Mise Éire (I am Ireland), features as the soundtrack of "1916" the centenary programme, narrated by Liam Neeson, which examines the 1916 Easter Rising in Dublin; this work was aired on RTÉ, February 2016.

In contrast to the ill-fated tragedy associated with the character of Déirdre, several Irish composers have engaged with heroic themes from the Ulster Cycle. Although Fleischmann sought to express a more modern compositional language and refuted any "slavish use of material of the past", his music output is steeped in the Irish literary heritage; however only two works engage with tales from the Ulster Cycle. These compositions employ heroic themes, namely the ballets Macha Ruadh (Red-haired Macha, 1955) and The Táin (1981). Fleischmann's short ballet, Macha Ruadh (1955), is based on the Irish philologist and celticist Myles Dillon's adaptation of the saga. The ballet is set in two scenes and depicts the warrior Queen Macha defeating Cimbáeth and subsequently declaring Emain Macha as seat of the High Kings of Ireland. Fleischmann dedicated his life to the development, and promotion, of music through Irish culture. When Fleischmann returned to Cork after his post-graduate music studies in Munich (1932-4), he was aware that Ireland had been seized by an essentialist protection of Irish identity which resulted in cultural isolation. The strength of his dedication is evident in his writing for the stage in that he forged a life-long collaboration with the dancer and choreographer, Joan Denise Moriarty, who formed a successful ballet company against all odds (R. Fleischmann). Irish heroism features in several of Fleischmann's works associated with the choreographer including the orchestral work, Clare's Dragoons (1945), ${ }^{14}$ in which Moriarty played the pipes, and the ballets Macha Ruadh and The Táin (1981). With regard to Macha Ruadh, the Irish musicologist and composer Séamas de Barra suggests that the ballet may have been "intended to convey a significant message." In reference to Moriarty, he claims:

A courageous woman, striving against the odds and ultimately victorious through sheer force of personality, succeeds in establishing a great tradition. Even if one 
cannot say with absolute certainty that this was deliberate and conscious selfmythologizing, it is unlikely that a discerning audience could have failed to draw a parallel between Macha Ruadh and Joan Denise Moriarty, especially as she herself danced the title role. On one level at least, the work seems to have been a projection beyond present difficulties to the eventual recognition of the ballet as a vital and intrinsic part of the cultural life of the country. (104)

Fleischmann's efforts in actively campaigning for better music infrastructures and education in Ireland and the fact that he conducted Macha Ruadh surely would have been recognised as "a vital and intrinsic part of the cultural life of the country".

Cú Chulainn is one of the most legendary figures to emerge from ancient Irish sagaliterature and his heroic exploits feature in several of the interrelated tales that make up the Táin. This literary corpus has had a definite socio-cultural influence across the creative arts as the tales reflect several social and cultural perspectives. Political references include Oliver Sheppard's bronze masterpiece The Death of Chulainn (1911) which was appropriated by Éamon de Valera (1935) and installed in the window of the General Post Office, Dublin, to commemorate the twentieth anniversary of the 1916 "Easter Rising". The geographic locale of the Táin, for example, is embraced by the internationally acclaimed Irish sculptor, John Behan, who installed welded steel figures of Cú Chulainn (2012) in the apt location of Dundalk town, to which the Cooley Mountains are a backdrop. Since the 1970s, an increasing number of Irish composers have been inspired by the saga which may, in part, be attributed to Kinsella's successful translation and rejuvenation of the epic in 1969. As Ciaran Carson succinctly notes: "had Kinsella not undertaken his translation, there would have been no public consciousness of Táin Bó Cuailnge" (xxiv-xxv). This appears to be true for Irish composers as prior to Kinsella's translation, no works seem to have been inspired by the saga.

Aloys Fleischman's The Táin (1981) is the first full-length ballet ever written by an Irish composer and pursues a heroic trajectory, with Cú Chulainn emerging as the triumphant protagonist. Engaging with a saga from the ancient manuscripts of Ireland enabled Fleischmann to embody his synthesis of the Irish literary heritage with art music. The "Girls' Dance" for example is based on an Irish sounding pentatonic figure which evolves through a series of permutations in order to create chromatic colour devoid of any specific tonality. To further emphasise the local features of the saga, Moriarty's movement vocabulary combines ballet with specific Irish dance steps including "tipping" and "battery" (Wallace). Despite a fleeting use of aleatoric and 12-tone techniques, the ballet fuses both Irish traditional and contemporary lexicons through a tonal context in an attempt to appeal to a wider audience and evidences how Fleischmann gives "new expression" to "the spirit of the traditional music" (A. Fleischmann, "Ars Nova" 45). ${ }^{15}$

In contrast to Fleischmann's heroic portrayal of the saga, James Wilson (1922-2005) composed a monodrama entitled The Táin (1971), which focuses on a tragic mythos that culminates in Cú Chulainn's killing of his foster brother, Fer Diad. The text was compiled by the music critic and broadcaster Ian Fox, from a variety of sources including Thomas Kinsella's recent translation. Typical of Wilson, he wrote the work with a specific performer in mind as he wanted to entice musicians to perform his music in order to establish himself as a composer of note in Ireland. Having moved from his native London to Dublin in 1948 to pursue a career in composition, engaging with Irish literature was one way in which Wilson attracted both performers and audiences to his music. In The Táin, he tailored the vocal writing to the capabilities of the internationally renowned Irish soprano, Veronica Dunne. Wilson's main concern is the enunciation of the words in order to portray a musical narration of the saga. The work, framed by a prologue and epilogue, is divided into two sections and 
relies on the classical conventions of aria and recitative imbued with a tonal compositional language; all of which convey a conservative attitude.

Three years later, based on another saga from the Ulster Cycle, Wilson composed a second monodrama for Dunne and adapted the text of Fand (1974) from the "The Sickness of Cúchulainn" (MacDonald). The striking difference between the two monodramas is that the role of the voice in Fand is integrated into the ensemble whereas the singer has the sole responsibility of convincingly portraying all the characters in The Táin. In Fand, Wilson illustrates the text through the blending of instrumental colours in order to create a type of dramatic sound-picture. Fand is a shorter work and tells of the goddess's love for Cú Chulainn as she helps him to recover from an illness that she has inflicted on him. Fand entices him to join her in the otherworld to help fight against her foes. When Cú Chulainn's wife Emer learns of the affair, Fand returns to her husband, Manannán mac Lir, who wraps her in his cloak causing her to forget about Cú Chulainn. Wilson's final work reflecting an Irish sagabased theme, The Only Jealousy of Emer (c.1983), is another tale from the Ulster Cycle for which the composer adapted the text from W. B. Yeats's play "Fighting the Waves" (1930). This incidental music for mezzo-soprano solo, horn and piano was commissioned by Jytte Abildstrøm and performed only once at the Riddersalen Theatre, Copenhagen in 1983. Although Yeats's work had gained global recognition, through the medium of music, Wilson brought the tale to an international audience. Wilson's Ulster Cycle works are not reliant on the context of the words to give his music meaning, rather he transcends the setting of the texts in that he did not feel the need to incorporate an Irish sound into his work.

Sétanta (2000) by Dundalk-based composer, Eibhlís Farrell (b. 1953), is unusual in that she employs both ancient and new texts, Old Irish and English, and also incorporates specific sounds from the Cooley area into the work. The choral work is divided into five sections, each of which is based on a selected theme, that refer to both romantic and tragic mythoi. In addition to employing Kinsella's translation as a source of inspiration, Farrell draws on two Irish-language texts derived from the earliest extant form of the saga in the eleventh-century Book of the Dun Cow, and from the most complete version of the saga in the twelfth-century Book of Leinster. The effectiveness of Farrell's simple writing, for the intended amateur performers, lies in the use of texture by which she creates specific sonorities to evoke the respective thematic sound-worlds. In Section 4 for example, Farrell's employment of Irish text is distinctly audible as it is presented in a homophonic manner. She makes use of a variety of tessitura beginning in the female vocal lines, progressing to the male voices and ending with the mixed choir. Farrell depends on the sound of this unusual language which complements the mysterious nature of the choir's commentary on Fedelm's prediction. The comprehension of the text is not important as it is put in context with Fedelm's words echoing throughout the section, often in a canonic texture - "I see red". The tragic outcome of Fedelm's prediction is reinforced by the predominant use of quartal harmony in the vocal and instrumental lines.

Farrell believes that the roots of the saga are embedded in her psyche, as she grew up in the Cooley mountain area, and was always fascinated that the location of the ancient world described in the Táin was part of her life. The pitch D is very significant in revealing how the roots of the saga are embedded in the composer's psyche as when growing up, Farrell constantly heard "a rich sonorous D" ringing from the local ninth-century bronze Bell of Bronach. In Sétanta she engages the pitch D as a pedal note that serves as an anchor throughout the composition (E. Farrell). The work opens with a modal sounding figuration D, $\mathrm{E}, \mathrm{G}, \mathrm{A}$, in the flute line, which is constantly interrupted by the solo voice intoning the pitches $\mathrm{D}$ and $\mathrm{A}$, perhaps as a means of imitating the overtones that sounded from the Bell of Bronach. The flute and solo soprano lines continuously interrupt each other in Section 1 however, Farrell extends the motif and it eventually culminates in an ascending D melodic 
minor scale in the harp line as Sétanta boasts that "his name will live forever". Centred on the pitch D, Farrell's choice of pitch material adds a distinct unifying sonority to the overall composition and is confined to simple motivic ideas which develop into either modal or diatonic scale-like patterns. The juxtaposition of modal and diatonic sonorities imposes a resonance with the past and serves as a backdrop to Farrell's portrayal of the tale. The work begins and ends in this simple manner, thus highlighting the uniformity of Farrell's compositional style. Farrell includes several Baroque features, such as the "modal technique" that evokes "a generalized atmosphere of antiquity" (Dervan 14). The use of long pedal notes, rhythmic ostinato patterns and the employment of canonic, contrapuntal and homophonic textures also musically capture the ancient world of the Táin. These techniques consciously reflect Farrell's fascination with early Baroque music, which is an intrinsic part of her compositional language.

John Kinsella's Cuchulainn \& Ferdia - Duel at the Ford (2008) was commissioned by Raidió Teilifís Éireann (RTÉ) to celebrate the $60^{\text {th }}$ anniversary of the RTÉ National Symphony Orchestra in a concert programme which included Beethoven's Piano Concerto No. 4 (1806, which according to Liszt refers to Orpheus and the Furies in the slow movement) and the final scene of Richard Strauss's opera Salome (which features the death of John the Baptist). These larger than life mythical and biblical figures inspired Kinsella (b. 1932) to focus on an heroic Irish character. At the time of the commission, the composer had recently visited Ann Meldon Hugh's bronze statue of a devastated Cú Chulainn carrying the slain Ferdia, in Ardee, Co. Louth, and since he is very familiar with his brother's translation of the saga, the idea to portray Cuchulainn \& Ferdia - Duel at the Ford evolved.

The title of Seóirse Bodley's orchestral work, I have Loved the Lands of Ireland (Symphony No. 2, 1980), does not make any explicit reference to ancient Irish literature, however the characters of Cú Chulainn, and the war goddess Morríghan, feature as the titles of the fifth and third movements respectively. The work was commissioned by the Irish government to commemorate the centenary of Patrick Pearse's birth (1879-1916). Bodley (b. 1933) allocated titles that are inspired by references to early Irish literature to each of the seven movements of the work as he wanted to pay homage to the Irish poet and educator who was one of the leaders executed for the 1916 Easter Rising. According to the programme note, the work "sets out to delineate the essence of the emotional and psychological history of the Irish people. In doing so it evokes three aspects of Ireland: reality, experience and myth". The composer considers "the 'lands' of the title in the sense of territories of the Irish mind and spirit". Myth is expressed in the form of Aislingí; the second Aisling, movement 5, is entitled "Cúchulainn" and the heroic warrior is depicted through "antiphonal effects" which symbolise "conflict and challenge faced with courage" (Bodley). "Morrígan", is the title of the first Aisling, movement 3, where "a sense of demonic gaiety pervades the music which is ominous and vigorous" (Bodley) and a trumpet solo evokes a sense of nobility only to be mocked by high clarinets.

In contrast to Cú Chulainn's heroic deeds, the war goddesses Macha and Morríghan feature in the titles of two works by Irish composers. The social and political upheavals in Northern Ireland stimulated the Belfast-born composer, Michael Alcorn (b. 1962), to title his orchestral work, Macha's Curse (1997). While several goddesses and heroines bear the name Macha, the most well-known figure refers to Crunnic's wife who imposed a curse on the men of Ulster when she was forced by the provincial King to race against a chariot while heavily pregnant. She immediately gave birth to twins and screamed out that the men who heard her pain would suffer that agony for nine days in their times of great need. ${ }^{17}$ The reference to Macha in Alcorn's Macha's Curse is however in name only as the orchestral work conveys the composer's personal response to the Troubles which have affected the people of Northern Ireland. Alcorn's response was aroused by the cease-fires of 1994 and he states that the work 
is "without political, programmatic or symbolic references" as his aim was "to capture some of the complex emotions which have touched so many lives in the [Ulster] Province" (Alcorn).

A progressive musical response to a character from the Ulster Cycle is Fergus Johnston's Morríghan (2000), scored for electro-acoustic and mixed media. This is the first work based on a tale from the Ulster Cycle written for an electronic medium. The sex and battle goddess, Morríghan, frequently changes form and her character features in several early Irish sagas; in the Táin, she appears to Cú Chulainn as an eel, a heifer and a seductive girl. When Johnston (b. 1959) was commissioned by the flautist, Eleanor Dawson, to write a piece for baroque flute, viol, harpsichord and electronics, he decided to deviate from the historically established compositional rubrics expected for a Baroque ensemble. Instead, the manner in which the acoustic instruments and synthesised instrumentation are employed determines a multifarious musical experience. The flute line for example explores a plethora of sonic expressions through the employment of several techniques such as delayed spit tones and bending notes. After establishing the design of the sonic context in which Johnston "shapeshifted" the sound of the flute into multifarious expressions, the image of the Morríghan sprang to the composer's mind as a possible encapsulation of the flute character that he had invoked. Johnston informed the author that his aim is always to "shape the music satisfactorily" and in this work he achieves a beautiful sound (a beautiful woman), a distorted noise (a hag), a simple instrument (a simple bird) and a complex chaotic instrument (a harbinger of death and destruction). ${ }^{18}$

\section{Conclusion}

Since the ancient sagas have become embedded in Irish consciousness and are an integral part of Irish historical and cultural life, engaging with this literary corpus has enabled each composer to identify with Ireland. Through the employment of ancient sagas from the Ulster Cycle, the composers studied contributed to the cultivation of a tradition of Irish art music and helped to bridge the divide between Irish art music and the Irish audience. Each composer's attitudinal response to the sagas reveals cultural ideologies - protectionist or progressive practices - that prevailed in Ireland at the time of their respective composition. As the discussion of works progressed from the nineteenth- to the twenty-first century, nationalist ideologies, where composers shared a common romantic language imbued with Irish traditional music, gave way to a more eclectic approach in that composers exhibited the confidence to embrace modernism on their terms and created distinctive personalised voices. Sweeney's "Hiberno-minimalism", Farrell's engagement with early Baroque music, and Johnston's writing for an electronic medium, for example, evidence how Irish composers have forged an individual identity within a pluralistic Irish culture. While several composers give their music meaning by relying on the context of the literature, others transcend the settings of the sagas. The extent to which each composer engages with the literature, however, is reflected in the stylistic construction of the music; an area that requires further investigation. This paper highlights new areas for description and it is evident that there is much scope for further research into the cultural significance of ancient Irish literature for composers.

\section{Notes}

${ }^{1}$ The orthography of Old, Middle and Early Modern Irish has no settled system of spelling however this study strives for consistency and therefore refers to those indicated in Bernhard Maier's Dictionary of Celtic Religion 
and Culture (1998), unless otherwise stated. In all cases, the composer's choice of spelling is used for the title of each work.

${ }^{2}$ An Irish composer is recognised as "anyone who was born or is permanently resident in the Republic of Ireland or Northern Ireland." This is the official definition on the Contemporary Music Centre website (Ireland's national archive and resource centre for new music), http://www.cmc.ie/composers. Unless otherwise stated, further information on all studied compositions is available at http://www.cmc.ie.

${ }^{3}$ The first German translation of "The Book of Leinster" text is by Ernst Windisch and the French translation is by Henri d'Arbois de Jubainville.

4 The first Feis was held in Dublin, 18-22 May 1897, and was co-founded by Irish composer Annie Wilson Patterson. It is still in existence today.

${ }^{5}$ See Klein 1996, 2003 and 2004-5, and Aloys Fleischmann 1936, 1952 and 1996.

${ }^{6}$ Bax's Éire trilogy is made up of three parts: Into the Twilight (1908), In the Faery Hills (An Sluagh Sidhe, 1909) and Roscatha (1910). The eminent Irish musicologist, Harry White, discusses Bax's musical and literary relationship with Ireland, particularly focusing on how the composer's creative imagination was imbued with the spirit of Dublin, and the cultural revival, during this time (White, The Keeper's 118-24).

${ }^{7}$ For further reading on "Celtic Legends in Irish Opera, 1900-1930" see Klein, "Celtic Legends" 40-53. Klein provides an introduction to his on-going study of Irish operas that were inspired by Celtic legends during a time when patriotism was very strong (1900-30) and also highlights the earliest saga-based works by Irish composers. For a list of saga-inspired works by Irish composers see Horgan Goff, "Cultural Constructs” 205-16.

${ }^{8}$ In 1950, Friel composed a ballet also entitled The Children of Lir.

${ }^{9}$ See also Graydon 56-79, for an informative account of how these composers embraced contemporary European techniques.

${ }^{10}$ For further reading on this exchange of opinion see de Barra 54-5.

${ }^{11}$ Examples of these reputable journals include the Irish Statesman (1919-30), Ireland To-Day (1936-8), The Bell (1940-54), and Envoy (1949-51).

12 O'Connor's play Deirdre was premiered at the Dublin Theatre Festival in 1979 and was later performed at the Abbey Theatre, Dublin, March 1986.

${ }^{13}$ For further reading on Sweeney's Níamh of the Golden Hair, see Horgan Goff , "Musical Interpretations" 8398.

${ }^{14}$ Clare's Dragoons was commissioned by Raidió Éireann to celebrate the centenary of Thomas Davis's death. In order to honour the cultural nationalist, the work is imbued with patriotic sentiment.

${ }^{15}$ For further reading see Horgan Goff, "Cultural Constructs" 67-72 and 100-133.

${ }^{16}$ For further reading on this work see Cox 95; 100-3.

${ }^{17}$ Kinsella's translation of the Táin includes this story as a pre-tale "The Pangs of Ulster" (6-8).

${ }^{18}$ Interview with Fergus Johnston; email to Horgan Goff, 22 March 2016.

\section{Works Cited}

Alcorn, Michael. "Michael Alcorn-Compositions". 2015. 22 January 2015. http://www.michaelalcorn.net/compositions/category/orchestral

Bodley, Seóirse. Programme note for I Have Loved the Lands of Ireland (Symphony No. 2, 1980).

Carson, Ciaran. The Táin: A new translation of the Táin Bó Cuailnge. London: Penguin, 2007.

Contemporary Music Centre, Dublin. 19 February 2017. http://www.cmc.ie

Cox, Gareth. Seóirse Bodley, Dublin: Field Day, 2010.

d'Arbois de Jubainville, Henri. Táin Bó Cúalnge, Enlèvement du taureau divin et des vaches de Cooley. Paris: H. Champion, 1907.

De Barra, Séamas. Aloys Fleischmann. Dublin: Field Day, 2006.

Dervan Michael. "Sadhbh Dennedy: Setanta Choir: Dundalk IT". Irish Times. 11 February, 2003.

Dillon, Myles. Early Irish Literature. Dublin: Four Courts, 1997.

Farrell, Eibhlís. Programme note for Sétanta. 7 February 2003. 
Farrell, Hazel. "Irish folk tunes and minimalist techniques in Eric Sweeney's Concerto for Guitar (2004)". Irish Musical Studies 11: Irish Musical Analysis. Eds. Gareth Cox and Julian Horton. Dublin: Four Courts, 2014. 247-258.

Fleischmann, Aloys. “Ars Nova: Irish Music in the Shaping”. Ireland To-Day 1. 2 (1936): 4148.

. "First Performances of Works by Irish Composers 1935-1951". Music in Ireland: A Symposium. Ed. Aloys Fleischmann. Cork: CUP, 1952. 171-5.

-. "Music and Society, 1850-1921". A New History of Ireland, Volume VI: Ireland Under the Union, II, 1870-1921. Ed. W. E. Vaughan. Oxford: Clarendon, 1996. 50022.

Fleischmann, Ruth, ed. Joan Denise Moriarty: Founder of Irish National Ballet. Dublin: Mercier, 1998.

Graydon, Philip. "Modernism in Ireland and its Cultural Context in the Music of Frederick May, Brian Boydell and Aloys Fleischmann". Irish Musical Studies 7: Irish Music in the Twentieth Century. Eds. Gareth Cox and Axel Klein. Dublin: Four Courts, 2003. 56-79.

Gregory, Lady Augusta. Cuchulain of Muirthemme. London: John Murray Publishers, 1902.

Horgan Goff, Angela. Cultural Constructs of National Identity in Irish Saga-Inspired Musical Composition. PhD Dissertation. Waterford Institute of Technology. 2014. 30 January 2015. http://repository.wit.ie/2897/

. "Musical Interpretations of Fenian Literature by Contemporary Irish Composers". New Crops, Old Fields: Reimagining Irish Folklore. Eds. Conor Caldwell and Eamon Byers. Oxford: Peter Lang, 2017. 83-98.

Kinsella, Thomas. The Tain from the Irish Epic Táin Bó Cuailnge. Oxford: Oxford University Press, 1970.

Klein, Axel. Die Musik Irlands im 20. Jahrhundert. Hildesheim: Georg Olms, 1996.

. "Roots and Directions in Twentieth-Century Irish Art Music". Irish Musical Studies 7: Irish Music in the Twentieth Century. Eds. Gareth Cox and Axel Klein. Dublin: Four Courts, 2003. 168-182.

- "Celtic Legends in Irish Opera, 1900-1930". Proceedings of the Harvard Celtic Colloquium, Vol. 24/ 25. 2004-5. 40-53.

MacDonald, John, trans. "The Sickness of Cúchulainn”. Scottish Gaelic Studies, 1. (1926): 137(?).

Maier, Bernhard. Dictionary of Celtic Religion and Culture. Woodbridge: Boydell, 1998.

Moore, Thomas. "Let Erin Remember the Days of Old". Poetry of Thomas Moore. Ed. C. Litton Falkiner. London: Macmillan, 1903. 15.

Ní Bhrolcháin, Muireann. An Introduction to Early Irish Literature. Dublin: Four Courts Press, 2011.

Ó Gallchobháir, Éamonn. “Atavism”. Ireland To-Day 1. 4 (1936): 56-8.

O'Rahilly, ed. Táin Bó Cuailnge from the Book of Leinster. Dublin: Dublin Institute for Advanced Studies, 1967.

, ed. Táin Bó Cuailnge: Recension I. Dublin: Dublin Institute for Advanced Studies, 1976.

— ed. "Introduction: I Recensions ot TBC". The Stowe Version of Táin Bó Cuailnge. Dublin: Dublin Institute for Advanced Studies, 1978. vii-viii.

Ryan, Joseph. "Nationalism and Irish Music". Irish Musical Studies 3: Music and Irish Cultural History. Eds. Gerard Gillen and Harry White. Dublin: Irish Academic, 1995. 101-15.

Sweeney, Eric. Programme note for Déirdre (1989). 1990. 
A Folio of original Compositions. DPhil dissertation. University of Ulster, 1994.

Synge, John Millington. Deirdre of the Sorrows. The Complete Works of John Millington Synge. New York: Random House, 1935.

Wallace, David. "Aloys Fleischmann and Joan Denise Moriarty: The Music and The Dance:

A Choreomusical Analysis of the 'Camp Maiden's Dance' from The Táin".

Conference paper. The First International Conference of Irish Music and Musicians. Durham University, 2010.

White, Harry. The Keeper's Recital: Music and Cultural History in Ireland, 1770-1970. Cork: Cork University in association with Field Day, 1998.

. The Progress of Music in Ireland. Dublin: Four Courts, 2005.

Windisch, Ernst, trans. Die altirische Heldensage Táin Bó Cúalnge nach dem Buch von Leinster. Leipzig: Hirzel, 1905.

Yeats, W. B. "Fighting the Waves". The Collected Works of W.B. Yeats Vol II: The Plays.

Eds. David R. Clark and Rosalind E. Clark. London: Scribner, 1930. 455-64.

Received: 19 February $2017 \quad$ Revised version accepted: 30 June 2017

Angela Goff (BA, HDE, MA, PhD) currently teaches history at Waterpark College, Waterford, and is a committee member of the interdisciplinary research forum "New Crops, Old Fields" at Queen's University Belfast. She has recently completed post-doctoral research, and co-authored a report, based on the creative and cultural industries of the South East region of Ireland as part of the Cultural Capital Research Project, Waterford Institute of Technology, Ireland. Her $\mathrm{PhD}$ explored cultural constructs of national identity in Irish saga-inspired musical composition, which focused on interpreting works by Frank Corcoran, Aloys Fleischmann, and James Wilson. Publications include "Musical Interpretations of Fenian Literature" (2017), "Peadar Townsend's Musical Portrayal of Fionn Mac Cumhaill's Adventures" (2015), and "Irish Identity in Fergal Carroll's Song of Lir" (2014).

agoff123@gmail.com 